\title{
HOW TO RAISE AN ENTREPRENEUR? FOSTERING ENTREPRENEURSHIP IN SLOVENIAN SECONDARY EDUCATION
}

DOI: 10.17234/SEC.33.2

Original scientific paper

Received:

24th May 2021

Accepted:

28th September 2021

\author{
SAŠA POLJAK ISTENIČ \\ ZRC SAZU \\ Inštitut za slovensko narodopisje / \\ Institute of Slovenian Ethnology \\ Novi trg 2 \\ SI -1000 Ljubljana, Slovenija \\ sasa.poljak@zrc-sazu.si \\ orcid.org/0000-0001-5277-7100
}

This paper is open access and may be further distributed in accordance with the provisions of the CC BY-NC-ND 4.0 HR licence.

The article uses a case-study of a Slovenian secondary school to discuss national specifics and European trajectories of entrepreneurship education. It is based on an historical overview of its development in Slovenia and narrative interviews with educators, headmasters, mentors, and students to illustrate how educational opportunities shape students' agency. Adding to the standard argument of the neoliberalisation of contemporary education in which students are seen as human capital, the article analyses how the school works with them in regular programmes and extracurricular activities to avoid neoliberal labelling. It fosters volunteering, addresses local problems, and encourages the critical assessment of the need to intervene.

Keywords: entrepreneurship education, secondary schools, (mitigating) neoliberalism, students-as-givers

\section{INTRODUCTION}

"I'm really sure that all of us, many of us, succeed because of the environment, while many people don't even try because of an unsuitable environment," 17-year-old Jakob ${ }^{1}$ explained to me when discussing his first successful entrepreneurial project. He had high praise for his school as well as his headmaster, who was given credit for

\footnotetext{
${ }^{1}$ I use pseudonyms except in cases of private entrepreneurs with a registered business who are also well-known public figures (see more in the methodology section).
} 
the school's fame in entrepreneurial circles.

When I came to the gymnasium, I saw that with motivation, with that strength, 'hey, you are capable, you can succeed.' That gave me the push, 'hey, Jakob, try it. You can.' Because before [I was not like that], my mindset at the time also changed. All these extracurricular things, I started to attend them at the time. Because I just saw that this is something worth building on, working on, investing time as well as money.

Jakob, having his first 'business' already under his belt, is a rare but not unheard-of case of an "entrepreneurial pupil" (Berglund et al. 2017:893) who already transformed his idea into a somewhat profitable project (potential business) in secondary school. Several secondary school children who attend different programmes from gymnasiums to technical schools in Slovenia have succeeded in launching their business ideas and even making some profit by the time they legally came of age or soon after starting at university. To encourage and support them, schools offer extracurricular activities in the form of entrepreneurship classes, youth hackathons, start-up weekends, and mentorships; some also cooperate with different platforms mimicking the current business world or adapting them to the educational environment (e.g., Junior Achievement and Headquarters of Learning Companies Slovenia). Students who do not have business ambitions also gain entrepreneurial skills and competences through the school's problem-oriented projects or interdisciplinary thematic sets (a cross-curriculum activity often linked to develop entrepreneurial skills).

To start answering the question of whether it is possible to talk about entrepreneurship education in regard to regular school programmes in the Slovenian school system, one needs to first define what exactly entrepreneurship education is. A literature review reveals diverse perceptions of the matter. According to the Mwasalwiba's (2010) review, researchers have understood the term as quite self-explanatory since very few have attempted to directly define it. Besides advocating for one of the related terms (entrepreneurship education, enterprise education, or entrepreneurial education, which are, on the other hand, often used interchangeably or are merged into the generic term 'entrepreneurship education'), the definitions generally reflect the major aims and objectives of such activities. These are mostly identified as "influencing individuals' attitudes, behaviour, values or intentions towards entrepreneurship either as a possible career or to enhance among them an appreciation of its role in the community (i.e., creating an entrepreneurial society)" or "the acquisition of personal skills in entrepreneurship" (ibid.:25-26). Polish economist Krzysztof Wach (2014:13) further clarifies such a dual understanding of entrepreneurship in the educational literature: it is either defined as learning a specific knowledge and mostly technical skills to start and run your own 
business or as gaining entrepreneurial capabilities, skills, and attitudes (when referring to a wider context of entrepreneurship theory). In this article, I understand the term in both dimensions, which also correspond to the traditional vs. neoliberal orientation of entrepreneurship education (cf. Fayolle and Klandt 2006:2) or, in certain cases, also as entrepreneurship education vs. enterprise education (cf. Lackéus 2017), and propose that it be used to understand not only extracurricular activities but also (with reservations) regular school programmes, at least at the secondary level that I have focused on, as an institutionalised variant of entrepreneurship education.

When assessing scholarship on entrepreneurship education, neoliberalism is the dominant recurring theme as analysed through documents and strategies at the international or national level (e.g., curricula and EU papers; cf. Dahlstedt and Fejes 2019; Laalo et al. 2019) or through educational initiatives and pedagogy (e.g., Brunila 2012; Robinson and Shumar 2014; Testa and Fracheri 2015; Berglund et al. 2017). Neoliberalism is a mode of (political) discourse that creates a specific common-sense way in which we interpret, live in, and understand the world as shaped by the free market (Harvey 2005). In an educational setting, it is often associated with an emphasis on the 'enterprising self' (Rose 1998) or 'entrepreneurial self' (Freeman 2014). The social domain is thus rephrased as an economic domain where 'homo economicus' brings economic rationality to his/her dealings in other spheres of life. It relies on the "technologies of the self" (Foucault 1988), which invoke individuals to take new subject positions within contemporary discourses and develop the characteristics and attitudes necessary in entrepreneurship (e.g., initiative/activation, independence, risk-taking, self-reliance, selfresponsibility, etc.).

This association with neoliberalism is closely related to human capital theory in which not only adults, but also children (and youth) are understood "as investment goods providing an income for the country or as future human capital" and consequently their education is seen "as the solution to maintaining the international competitiveness of national economies" (Millei 2020:930-931). Researcher of early childhood education Zhuzha Millei further underlines that "[g]overnment programs approach children as economic investments [... whose] returns are calculated in two ways: first, as the knowledge, skills, and competencies that facilitate the creation of personal, social, and economic well-being, and second, as a means of saving on welfare spending" and points out that such an understanding has provided the ground for restructuring schools and changing pedagogical approaches to teaching and learning (ibid.:931). Two ways referred to by Millei correspond to the dual understanding of entrepreneurship education described above (gaining entrepreneurial competences vs. starting a business). The start of this trend has been usually linked to the Lisbon strategy (cf. Glas et al. 2006:100; Laalo et al. 2019:93) while its persistence is proved by the latest analysis of distance 
learning, which was profoundly institutionalised by the COVID-19 pandemics, as a new form of coercing children into entrepreneurial work ethics (Turk Niskač 2021).

However, despite the global reach of human capital theory and related entrepreneurial concepts that prompt a universal understanding of the effects of neoliberalism on education, becoming an "ideal neoliberal subject" (Houghton 2019:620) is tied to national specificities that young people encounter and try to make sense of (Honeyman 2016; Kozorog 2018a, 2019). The first aim of this article is therefore to fill the overlooked area in the study of entrepreneurship education in Slovenia by providing further contextualisation for research on young entrepreneurs in the country (Bajič 2015; Poljak Istenič 2015; Vodopivec 2017, 2018; Kozorog 2018a, 2018b, 2019; Benak Cvijanović and Dopler 2020), which has been predominantly conducted through the critique of neoliberalism. On the other hand, to add to the standard analysis of the neoliberalisation of contemporary education, the article also takes into consideration the schools' awareness of such a critique and their attempts to deflect it, echoing Martin Lackéus's (2017) attempt to look for practices and approaches that might mitigate neoliberal tendencies in education.

\section{METHODOLOGY}

This research has been a part of the project Young Entrepreneurs in Times of Uncertainty and Accelerated Optimism: An Ethnological Study of Entrepreneurship and Ethics of Young People in Modern-day Slovenia. ${ }^{2}$ I focus on the issues of how the Slovenian education system educates children in entrepreneurial thinking and what teachers' attitudes towards this field are, how they are trained for this task, and who controls and directs the education.

The article is based on materials, documents, and articles that analyse the history of entrepreneurship and entrepreneurship education in Slovenia, and - to a much wider extent - on interviews with educators from the business sector who cooperate with schools, as well as headmasters, mentors of entrepreneurial classes, secondary school students, university students who registered a business based on the ideas they started to develop in secondary school, and students pointed out to me for having strong entrepreneurial competencies and who still cooperate with their formal secondary schools. I used the snowball method to find interlocutors. At the beginning, I contacted Matija Goljar, the founder of the "entrepreneurial sandbox" Ustvarjalnik [the Creator Institute], which developed a model for entrepreneurship classes for schools

\footnotetext{
${ }^{2}$ The project (J6-1804) has been supported by the Slovenian Research Agency.
} 
and other types of support mechanisms for (future) young entrepreneurs, and Nastja Mulej, a trainer, facilitator, and consultant on creativity, innovation, leadership, and collaboration who is currently engaged by the Ministry of Education, Science and Sport as a consultant in strategic development of entrepreneurship and regularly conducts workshops for children and training for teachers and companies. I interviewed them about the system of entrepreneurship education in Slovenia and asked them for contacts of people who would have something to say on this topic. They further recommended the people they were familiar with.

The snowball method was used for two reasons. First, ethnographic observation was not possible due to the closing of schools and exclusive online education at the time of the research; even when schools reopened, access to schools was prohibited for outsiders (non-students and non-employees). The only remaining way to contact students in line with the General Data Protection Regulation was thus through headmasters and teachers. Second, my focus was on the role-models of entrepreneurship education - schools and students - to understand why they were defined as exemplary and to explore their attitudes to entrepreneurship and, in particular, entrepreneurship education, which set them apart from other schools and indicate a desired direction of the system's development.

The sample consisted of 15 interlocutors, i.e., eight students, three teachers from secondary schools, two educators from the business sector, and two government officials. I deliberately left out non-entrepreneurial students and educators who would, on the one hand, certainly have shed light on the less obvious impacts of such an education, but, on the other hand, also would have widened the focus of the research, which was to study exemplary subjects. While the study was better streamlined due to such an approach, it needs to be noted that such a limited sample does not provide the ground for generalising the findings.

Due to epidemiological measures limiting face-to-face contacts, interviews were conducted through the Zoom application, recorded, and later transcribed. Interviews with individual students and (as an exception) teams were chosen as the most suitable method for online research in order to ensure a space that was as intimate and safe as possible for (also some underaged) students who shared potentially sensitive stories of interactions with teachers and family members. The narrative interview proved to be the most appropriate form; due to the diversity of interlocutors, it was difficult to anticipate and plan questions in advance. I initially asked them for a brief introduction, and the subsequent questions followed the flow of their thoughts.

I followed standard human subjects ethics. ${ }^{3}$ All respondents I contacted agreed

\footnotetext{
${ }^{3}$ Slovenia does not have a national framework for research integrity. Research in non-medical fields
} 
to participate voluntarily. I informed them about the course of the research and the planned forms of dissemination and asked for their consent to use the interviews for dissemination. I sent them a draft of this article and received written consent to have their remarks published. Despite their favouring the use of their real names, I anonymised the interlocutors (except Nastja Mulej and Matija Goljar, who are well-known public figures in entrepreneurial circles) in line with general anthropological practice.

The article focuses on the interviews of current and former students and the headmaster of one secondary school, referred to in the text as a gymnasium, while the others are used for the contextualisation of entrepreneurship education in Slovenia. The gymnasium was chosen as a case-study for two reasons. First, entrepreneurs pointed it out as one of the 'best practices' for encouraging students towards entrepreneurial careers. Schools that are nationally exposed as role-models can serve as an example of a wider trend of entrepreneurship education. They reflect a general process of shaping the programmes that teach students the entrepreneurial skills that are perceived as necessary for their future careers (and life in general) (cf. Benak Cvijanović and Dopler 2020). The second reason why I think the school provides for an indicative case-study is that the gymnasium's management is very aware of the pitfalls of neoliberalism as related to entrepreneurship education and entrepreneurship itself. It addresses its negative (controversial) perceptions and impacts while promoting entrepreneurial skills and competences informed by humanistic values. This has resulted in the internalisation of not only 'commanded' entrepreneurship by some of its students, but also in the school's attitude towards this phenomenon.

The article first briefly focuses on the history of entrepreneurship education in Slovenia, which has the national specifics of a post-socialist country while it also reflects the impact of European strategies that expanded the perception of entrepreneurship from making a business to developing competencies. It then shows, through three stories of (current and former) students from the chosen secondary school, how school opportunities shaped their agency and, finally, analyses how the school works with students to avoid accusations of neoliberal entrepreneurship education.

generally does not require an ethics committee clearance for national funding, so a human subjects research ethics review process has not been established. There is no ethical review board at the institution I am affiliated with. 


\section{THE HISTORY OF ENTREPRENEURSHIP EDUCATION IN SLOVENIA}

In recent decades, entrepreneurship has been emphasised as crucial for each country's ability to compete in the globalised 'knowledge-based society' (Dahlstedt and Fejes 2019:462). Following the genealogy of entrepreneurship education in a particular country thus reveals national specifics in shaping a curriculum as well as the influence of international trends and shifts.

Entrepreneurship in Slovenia started to flourish only after 1988, when the Yugoslav Companies Act [Zakon o podjetjih] was adopted, as it allowed private capital to be invested in companies. After independence, Slovenia tried to encourage entrepreneurship initiatives with the Small Business Development Act [Zakon o razvoju malega gospodarstva] adopted in 1991. In 1992, the state also established the first public institution for the support of entrepreneurship within the Ministry of Small Business, namely the Small Business Development Centre [Pospeševalni center za malo gospodarstvo], which has been restructured several times and currently operates under the name SPIRIT Slovenia - the Public Agency of the Republic of Slovenia for the Promotion of Entrepreneurship, Internationalization, Foreign Investments and Technology [Javna agencija RS za spodbujanje podjetništva, inovativnosti, razvoja, investicij in turizma].

The consequences of legislative shifts and institutional support in the 1990s included, in addition to the growing number of new small and medium-sized private companies, the establishment of the first forms of training and education for entrepreneurs (schools and courses); state support for entrepreneurship in the form of business incubators, entrepreneurship-innovation centres, clubs for the promotion of entrepreneurship initiatives, consulting centres, and projects for the development of infrastructure in entrepreneurship; the organisation of conferences on entrepreneurship and other forms of cooperation with foreign experts and institutions; and courses on establishing and running companies (Plut and Plut 1995:44). As assessed by Glas et al. (2006:101), Slovenia developed quite a broad range of training activities for entrepreneurs and staff in small and medium-sized enterprises (SMEs) in the 1990s as well as a "new curricula [in higher education] focused on entrepreneurship and SME management. Among the pre-conditions for entrepreneurship, according to GEM research [Global Entrepreneurship Monitor research done by the University of Maribor; cf. Simonič 2021], Slovenia scored well in the area of education and training."

GEA College, an entrepreneurship training centre, which was established in 1990 by 43 entrepreneurs as the initiative of a group of entrepreneurs and professors at the Faculty of Economics at the University of Ljubljana (Gea Colleage [s. a.]), was the first 
private initiative dedicated to entrepreneurship education in Slovenia. Among the early companies that started educating young people in Slovenia about entrepreneurship was the company Sun from Gornja Radgona. It focused on both unemployed youth and students (albeit at different times). In 1995, it began to run entrepreneurship classes in elementary schools "to contribute to the creation of a positive entrepreneurship culture" (Sun [s. a.]) and educate (or train) mentors for entrepreneurship classes; the movement covered a good quarter of all primary schools in Slovenia (123 out of 446 in 2003; cf. Statistical office 2005).

As noted by Glas et al. (2006:13), entrepreneurial activities, such as those described above, were numerous and developed at all levels of education at the turn of the century. However, they were implemented by individual institutions or local authorities (often in partnership), which means that the initiatives were often isolated and not part of a coherent programme. They were more often encouraged by external factors than by the school system itself, and entrepreneurship was generally taught as a single subject or as an activity outside the formal curriculum, which, in the absence of a national strategy, significantly reduced general access to entrepreneurship education. The same was noted at the time by the European Commission for education in the European Union.

The European Union influenced another legislative and strategical shift in entrepreneurship policies in Slovenia (cf. Bajuk Senčar 2021), which was already reflected in the terminology; instead of the word 'entrepreneurship' [podjetništvo], the term denoting the 'quality of being enterprising' [podjetnost] entered the general vocabulary. This shift can be traced back to the Lisbon strategy (2000), which attributed education a key role in making the EU "the most competitive and dynamic knowledgebased economy in the world" and ascertained that "Europe's education and training systems need to adapt both to the demands of the knowledge society and to the need for an improved level and quality of employment" (Lisbon European Council 2000). Similarly, the Green Paper Entrepreneurship in Europe advocated that "[e]ducation and training should contribute to encouraging entrepreneurship, by fostering the right mindset, awareness of career opportunities as an entrepreneur and skills" (Commission of the European Communities 2003:12). Entrepreneurship was linked with lifelong learning and declared a key competence for all citizens in 2006 (European Union 2006), thus becoming a broad educational theme in European education policy. The Europe 2020 strategy further enhanced this agenda and recommended that governments should "focus school curricula on creativity, innovation, and entrepreneurship" (European Commission 2010:11).

The national indicators of this shift were, first, the Support Environment for Entrepreneurship Act [Zakon o podpornem okolju za podjetništvo] from 2004, which 
promoted forms of networking between research and educational organisations and the companies and, second, a strategy for introducing entrepreneurship into the regular school system and an introduction programme for the period 2007-2013 (Glas et al. 2006), which was published in 2006 but never materialised in practice. Furthermore, different programmes and measures have supported the introduction of entrepreneurship into school curricula; currently, the Youth and Entrepreneurship programme run by SPIRIT Slovenia supports training for teachers and lecturers, provides incentives for schools to carry out activities with young people, promotes the development of young people's business ideas with mentoring and funding of further business ideas (in cooperation with support institutions at the national, regional, and local level), and co-organises the POPRI competition for young people's entrepreneurship ideas (Mladi in podjetništvo [s. a.]; for more about POPRI, see Benak Cvijanović and Dopler 2020).

Entrepreneurship [podjetništvo] in Slovenia - and later activities for students to gain the qualities of being enterprising [podjetnost] - thus slowly penetrated all levels of education, from universities to primary schools, from regular (full-time) to part-time education, from systemic to extracurricular activities. Children in primary schools are now encouraged "towards the development of general competencies useful in everyday life" (Trampuš 2016), i.e., creativity, thinking, and problem solving. In secondary school and in tertiary education, more emphasis is put on entrepreneurship and the development of specific entrepreneurial skills (Poljak Istenič 2017:107) - but not in all circumstances and forms, as will be shown below.

\section{DEVELOPING ENTREPRENEURIAL KNOWLEDGE AND COMPETENCES: A CASE-STUDY OF A GYMNASIUM}

When neoliberalism entered the educational system, it "introduced a new mode of regulation or form of governmentality" (Olssen and Peters 2005:314), which functions through "technologies of power" and "technologies of self" (Foucault 1988). Students are simultaneously targets of governing and active shapers and controllers of themselves (Lallo et al. 2019:97). This section uses examples of three (current and former) students of a gymnasium to show how "technologies of power", i.e., opportunities provided by the school, supported students as potential entrepreneurs but also shaped their agency ("technologies of self") to submit to and take advantage of such opportunities.

When I asked the headmaster of the gymnasium about the history of introducing entrepreneurship in the school he oversees, he explained: 
Entrepreneurship in an unsystematised form has been present in our school for a very long time, because it is [...] one of the key identities of the gymnasium, which in a way addresses those who enrol in it; it is an opportunity to implement various ideas. The school has always been in favour of $[. .$.$] this student activity, especially within the student community,$ especially in the field of volunteering, which has, in recent years - since we have dealt with this matter more systematically - transferred quite strongly into the field of social entrepreneurship or, let's say, some entrepreneurial competencies with these values.

The school implements three programmes - gymnasium (general programme), art gymnasium (visual arts), and pre-school education - as well as 'enrichment activities', which include compulsory and non-compulsory elective subjects, school, national and international projects (funded by the Erasmus + programme and the European Social Fund), excursions, and extracurricular activities. There were as many as 49 extracurricular activities in the school year 2020/21, ranging from languages, public speaking, art courses, science classes, physical activities, chess, gardening, and volunteering for specific school events or activities and projects for local communities. The entrepreneurship class was among them and was supported by SPIRIT Slovenia.

The entrepreneurship class has been (with a short interruption) operating since 2014. It was initially implemented by the association Ustvarjalnik [the Creator Institute], which developed its own model for promoting entrepreneurship in primary and secondary schools. Their mentors were typically young entrepreneurs who taught children entrepreneurial skills. Later, Ustvarjalnik focused on a foundation to support young people with promising entrepreneurial ideas and, thus, the class was taken over by the gymnasium's former students. They invite experts and entrepreneurs as guests, prepare lectures on topics related to entrepreneurship, coordinate groups that develop entrepreneurial ideas, and communicate with students.

One of the most entrepreneurially successful students, who attended the entrepreneurship class under the mentorship of Ustvarjalnik, is Mina, who sells handmade dog equipment. According to her description, the class relied on debates on what they like to do, what their hobby is, and how they could turn it into a business while they also gained some entrepreneurial skills. For example, they were given a box of cookies that they had to sell for voluntary contributions. Through succeeding to earn some money or failing to persuade people to buy it, the students learned about the ups and downs of entrepreneurship and, in the words of the headmaster, "understood that there is no problem... if they propose or develop something or recognise that it is not working." In the second year of her secondary education, the activity was on hiatus, 
so she independently researched the market and developed products. In the third year, she got into Ustvarjalnik's programme Foundation for Creative Youth [Fundacija za ustvarjalne mlade], which has provided her with a small 'scholarship', a mentor to work with, business connections, and opportunities to socialise with entrepreneurial peers. At the same time, the school supported her entrepreneurial path by granting her the status of a 'successful student', which enabled her to work for the company registered under her parent's names - during classes and to adjust school obligations to her schedule.

When she compared what she learned in the school's entrepreneurship class and as Ustvarjalnik's scholarship holder, i.e., in the public and private ecosystems, she emphasised that "both principles are great for someone who is at the beginning." The difference is mainly in mentoring - one person mentored several students and helped them in the school's entrepreneurship class while she had a mentor who focused only on her at Ustvarjalnik. As she noted, both methods have good and bad points: "For example, at the class [in school] it was nice to listen to a lot of other people, get advice, learn a lot from them. While one-on-one mentoring [at Ustvarjalnik] is much more focused on what you want, what your steps are, how to do something."

Jakob, mentioned at the beginning of the article, also attends the entrepreneurship class. He published a children's picture book explaining why we wear masks during the pandemic. However, his idea did not come out of the class, but from the so-called 'Entrepreneurship Week' to which the school invited external lecturers, which was supported by the SPIRIT Slovenia agency. The participants discussed the current situation with coronavirus and measures to prevent it, "how to identify, look for some opportunities that are entrepreneurial in the sense that they are sustainable, that they are self-sufficient, and on the other hand, that they have another effect, not just a consumerist one," explained the headmaster. Jakob had his own story to tell the kids, but this entrepreneurship [i.e., what he learned in entrepreneurship class] somehow let me know that something more can be made out of it, that it isn't so impossible. But still [...] I was still a little green. And then our headmaster played a very big role here, because I just sent him a story and told him a little about what I would do, but that I didn't know exactly how. And he was the one who said, 'let's do it, come on, let's do it'. That really helped me a lot. Mainly, it seems to me, not because of advice, but encouragement. That he believed in me was the most valuable for me. Because at the time, when I didn't quite believe myself whether I could actually succeed, he believed. And that was what [was driving me] when a bunch, really a bunch of problems I didn't expect came up. I thought, having an illustration, a story, a print, this is it. But no. 
When explaining the problems, Jakob mentioned proofreading, the identification number, permission from the Public Book Agency, cataloguing-in-publication, searching for a printing house, financial coordination, advertising, sales, a website, an online store, invoices, and book packaging. "But this challenge, this whole story, this project has given me a lot so far. More than any project so far. I really learned."

According to the headmaster, it took only a month from the idea of the book to its publication. With pictures and simple text, it explains to children between the ages of three and six - as well as to the older ones - why adults wear masks and do not socialise. "And it's exclusively the work of the pupils," the headmaster emphasised, and "the school merely provided money for the printing. But the investment has already been repaid and some profit has actually been made." Jakob's ambition is to make the hero of the book an actor of the younger generation for a wide variety of social issues; he is currently writing a book on reading.

Klemen is a former student of the gymnasium who, according to the headmaster's explanation of why he would be a good interlocutor,

is really planning huge voluntary projects [...] He also has, although he will never admit it, an entrepreneurial streak, he has it. Above all, he strongly attracts people with his enthusiasm. [...] He was never involved in the entrepreneurship class, but he always knew how to use it to support him in his projects.

Klemen's best-known work is a humanitarian project, which grew out of a fundraising action for a crisis centre for children, in which five students took part; or, as he explained, "from one of my mistakes I made, and I was very sorry. And I said to myself, ok, but l'm going to do something, something that's good, so in 2017 we started with charity projects at the gymnasium." He conceived a solidarity charity project aimed at activating young people and the wider community (parents, individuals, schools, kindergartens, and companies), motivating them to identify social issues in the environment in which they live and respond to them with action. It focuses on risk groups in the local environment (young people with fewer opportunities, the elderly, the socially excluded, etc.), animals, and the environment (cleaning campaigns); it is also supported by the EU through the European Solidarity Unit. In 2020, one hundred volunteers took part in the project, which makes him "very happy because our team is expanding and growing every year, which means that young people are active, they want to help each other, they want to be good, and I am really pleased to see it."

Klemen now studies pre-school education at the university and works in a private non-profit institution as a project assistant. He is not considering turning his experience with charity projects into a career, 
because I strictly separate the charity and [...] business side. [...] But still, it seems to me that these competencies that I acquire in my project, [...] leadership and communication competencies, definitely help me on this business path as well. That is to say, they shape me in a way and at the same time I get a really quality experience.

He recently published a children's picture book at the institution where he works and is planning another book to communicate the values he cherishes and tends to when volunteering.

These three short biographies of entrepreneurial students reveal the diverse opportunities provided by the school, which they used to develop certain skills and/ or fulfil their 'entrepreneurial' ambitions. An indicative observation is that they all evaluated them as distinctly positive despite the fact that some of them, at least to a certain extent, rejected submitting to the appeal of entrepreneurship. In view of the fact that I cannot draw a reliable conclusion of the (positive) general experience of such an education based solely on the three role-model students' narratives, I can nevertheless illustrate how the school created a stimulating environment for developing their talents and supported them in pursuing their interests. As such an approach is often negatively labelled as neoliberal, I use the next section to provide an insight into how the school tries to avoid the negative perception of entrepreneurship education.

\section{RECONCILING THE CRITICAL AND PRAISING PERSPECTIVES ON ENTREPRENEURSHIP EDUCATION}

Critical researchers of entrepreneurship education claim that it has profoundly triggered neoliberalism in education. Catherine Honeyman (2016) shows how new policies oriented local educational systems towards raising young people to adhere to a neoliberal ethos of self-reliance and personal responsibility, especially regarding employment and the distribution of state services. Researchers have particularly analysed the negative effects of entrepreneurship education in relation to, for example, gender, race, class, and other inequalities in specific local contexts (Valdez 2011; Wingfield and Taylor 2016; Berglund et al. 2017) and show that the

ideal individual qualities of an entrepreneur - such as competitiveness, independence, the need for achievement, and [a] willingness to take risks

- have set a norm that has excluded feminine characteristics and justified middle-class and masculine values as bases for entrepreneurship. (Komulainen et al. 2011:348) 
Furthermore, some empirical research shows that some teachers at all levels of education see the policy pressure to infuse entrepreneurship into education as highly problematic because it introduces capitalist and egoistical values at the expense of humanistic values such as equity, participation, and the common good (Lackéus 2017:635-636).

The gymnasium's headmaster also acknowledges that some teachers are critical of the introduction of new teaching models in which entrepreneurial skills are developed, so the concept of entrepreneurship (as knowledge and quality) are (discursively) avoided at school. On the other hand, he also finds this a problem of labelling, as the Slovenian language does not distinguish between the terms 'entrepreneurship' and 'business'.

An entrepreneur is a tycoon, ${ }^{4}$ I don't know, let's say, let's say, from the point of view of a very sharp critic belonging to one extreme ideological framework. They're tycoons, all in a row. Young tycoons. We are now teaching them how to 'tycoonise' what is not yet 'tycoonised'.

His view is also supported by Nastja Mulej, who is often hired by schools and companies to train employees (teachers, creative workers, project leaders, workers in administration, etc.) in Edward de Bono's methods of lateral thinking (cf. Dingli 2009).

People hear about entrepreneurship and slow down, they step on the brake because they think, aha, the quality of being enterprising / is entrepreneurship / is tycoonery. [...] By no means can people come to terms with the fact that, at the moment, our education is still teaching people that they are either an extended arm of a machine or an extended arm of a boss. That is, it does not teach them to be in any way independent, to cooperate under the guidance of a man who knows where [to lead development]. [...] Manual work is what counts more than mental work, service counts more than independence, and then they think now the ministry wants all the children to be independent entrepreneurs doing [...] precarious work.

To develop a deeper understanding of the relationship between entrepreneurship education and neoliberalism (negatively summed up by the term 'tycoon' in the interviews above), Martin Lackéus uses a Hegelian dialectic method to conclude that entrepreneurial education based on a self-oriented search for [one's] happiness leads to more neoliberalism in education, and entrepreneurial

4 'Tycoon' indicates a very wealthy and influential entrepreneur with strong political connections who controls the economy through networks and other means (cf. SSKJ 2014). 
education based on an others-oriented search for a meaningful impact on others mitigates some of the already strong neoliberal tendencies in education. (Lackéus 2017:636)

He defines two opposite orientations of students, "students-as-takers [as the] neoliberal self-oriented economic men searching for [their] own pleasure, power, freedom and wealth" and "students-as-givers [...] as others-oriented creative team players striving for meaning and impact" (Lackéus 2017:643). He proposes that schools infuse entrepreneurship into education through implementing the "studentsas-givers" perspective that provides positive feelings of meaningfulness, engagement, motivation, and deep learning in the entrepreneurial process of creating something of value for others. "Allowing students to become fully engaged and take part in an action-based team effort to help people outside their own class or school could rather be viewed as the logical opposite to neoliberalism" (ibid.:644). This would, in his opinion, comfort teachers, headmasters, as well as policymakers worried about the infusion of capitalist values in education and establish entrepreneurship as meaningful and creative acts for the benefit of others (ibid.:645).

This view is echoed by actors of the gymnasium when discussing the effects of neoliberalism. On the one hand, the notion of entrepreneurship (in terms of creativity and diverse activities) has been a strong denominator in the school's approach to education, representing the base of its identity and even its 'competitive' advantage (in terms of attracting students) and is, thus, supported by the staff. On the other hand, the teachers have often expressed concerns about the consumerist aspect of entrepreneurship and fears that whatever is not part of the curricula and deviates from the established (traditional) methods of teaching will negatively impact the achievement of the set goals and student's results in external evaluations (the Matura exam). Explaining the school's organisational dynamics (which are, however, similar to situations in other schools I studied), the headmaster described what they have done discursively and practically to mitigate the teachers' uncertainties and possible negative impacts of such a (neoliberal) educational approach. Among other things, they do not highlight "entrepreneurial competencies" but rather individual competencies that reflect humanistic values, e.g., cooperation, and test different approaches to teaching that would add to this goal.

Two years ago, they formed an informal group of teachers who favour different, novel pedagogy to teach students - experiential, project and team work as well as cooperation with actors (societies, companies, etc.) from the school's surroundings, local partners, and guest lecturers. They started to test these different approaches with one class of students who otherwise follow the same curriculum that applies to all other classes and who have their knowledge tested in the same way. Students who are 
now attending the second year are encouraged to have self-initiative and cooperate with each other and with other generations, which, according to the headmaster, also leads to an awareness of responsibility that suits these years, that is, the older a teenager is, the more independent he/she should be. [...] This should be a fundamental task of adolescence - to eventually become independent. If we transfer that task to the entrepreneurship framework, that's actually it. To make the best of things. But that you don't do well for yourself at any cost and without some, l'll say, moral norms. But that when you make the best of things, you always know how to think about a community and some of the consequences of your actions that you will need to accept.

The success of this class compared to others in which they have maintained a 'classic', frontal mode of teaching, convinces some more teachers each year to try new pedagogical methods (aimed at latently developing entrepreneurial skills and competences; cf. Honeyman 2016). Analyses have also shown that students from the 'test' class "feel less distance" towards their teachers and cooperate better.

"Those 'neoliberals' attend the entrepreneurship class while we had to go for a different rhetoric [in regular classes]," the headmaster further explained. This strategy did not just reassure the teachers. It has, as indicated in the interviews, instilled an ethical attitude in students; thus, they do not perceive their projects as business, even if they have a certain financial impact (such as Jakob's and Klemen's books). Their success is communicated to them in other (i.e., non-financial) ways, through social effects, e.g., through the social network they have woven and how they have given a voice to those who do not have it in society. The school therefore also promotes and implements projects "with a multiplier societal effect":

But there's really a very, very strong emphasis on the awareness of how much we can actually do with what we have, no matter at what wealth point we are. Do for a fellow human being. For the world. For classmates. For the community. [...] Because it seems to me that with this value, no matter where the path takes you, we will also be able to educate, in this purely entrepreneurial sense, staff who will feel responsible for the setting without which they could not have achieved anything. And that you are also aware of some history that led you to this point: a family, a school setting, some mentors, some support that you had at some point in your life - you always have to think about that when you decide what you will return [to society]. [...] Is it just a question of what is good for me or are you able to ask yourself whether what you are going to do is really good for everyone else? 
This philosophy has also been 'adopted' by the students. Marko, the former student of the gymnasium who still cooperates with the school - he mentors children preparing for the competition of young physicists - confirms that

talking about neoliberalism and entrepreneurship as one and the same thing is one such very lay interpretation, but I believe that it is very common. It's one thing to think entrepreneurially, it's another to give the market a free hand. Giving the market a free hand is idiotic. Because when we give free rein to the market, we have TikTok. If we think entrepreneurially, we know how to direct resources to the right things. It doesn't matter what those right things are, whether it's music, whether it's physics, whether it's chemistry, whether it's art, whether it's anything else, whether it's languages. If we know how to direct the means to a certain future, not only to study what we will get from it tomorrow, but what the man who is with us will have in ten, fifteen years from the thing we have just given him, then this is entrepreneurship, which needs to be developed. However, there is definitely no need to develop an entrepreneurship that focuses only on tomorrow, on how to make money quickly. This is not entrepreneurship for me.

In this sense, he also evaluates entrepreneurship classes, which he finds misguided when students develop business ideas, design products, and try to sell them as quickly as possible. "But entrepreneurship shouldn't be that. Entrepreneurship must look twenty years ahead. And see where the world wants to go [...] and be able to direct knowledge and interests exactly in that direction. To help people get where they want to go."

In his opinion, the school knew how to approach entrepreneurship. The headmaster, specifically, did not influence the students with authority, but provided them with what they wanted, and therefore got close with the students and positively impacted them. For example, Marko referred to his own understanding of entrepreneurship, which is based on the headmaster's:

In entrepreneurship, the last person you look at is you. You never look at yourself, you always look at others. You always have to ask yourself where this thing I'm doing will be in ten years. Whom does it help, for whom is it good, do I do more good than bad? Also, every time I tackle anything, whatever I do, I always ask myself, will more good or more bad come out of it? Will anyone be affected by what I do? Because today, everything they call entrepreneurship is based on exploitation. 
In this spirit, Klemen also rejects the idea of building his career on his humanitarian project and his other voluntary endeavours. Comparing voluntary (charity) and non-charity projects implemented at the gymnasium, he emphasises that with cooperation in any of them

you get some added value through strengthening mutual help, on which we really have a great emphasis at school. And also [the emphasis is] on educating young people. That is, not only through formal, but also through informal education, through what we are not theoretically taught in school, but what really influences the course of work. For example, it sometimes happens that an hour of Slovene, English, any subject is dropped, so that we can help, students help to carry things to the van when we need to take them to a collecting place or to crisis centres. And it seems to me that this is really a good example of ethical education, which I strongly advocate. Sometimes you see that you have to go a little off schedule, beyond some rules, to help others. And I think it's very nice that the gymnasium encourages some criticism from young people, expressing their opinion, constructive opinion and, of course, empathy and helping others.

The interviews indicate that the school consistently implements the perspective of 'students-as-givers' to create feelings of meaningfulness and value for others, building on humanistic values such as cooperation, mutual help, and empathy. It directs students to consider the impact of one's actions and to observe the acute social and environmental problems in the local environment. This policy also results in reduced concerns in some teachers about the neoliberal characteristics of such an education, encouraging them to test new approaches to teaching and working with students that help to raise 'students-as givers'.

\section{CONCLUSION}

The secondary school years seem especially fruitful for fostering values and entrepreneurship. According to Matija Goljar, head of Ustvarjalnik [the Creator Institute], primary school children do not yet have the necessary perseverance and need a lot of guidance, while university students are already too moulded and difficult to divert. Secondary school is thus such a "sweet spot in the middle [...] when people already have enough broad-mindedness and knowledge and self-discipline to do something, but [they] are completely unencumbered about what the world should look 
like." Similarly, Marko says that it is necessary to arouse interest, playfulness, and curiosity in young people who are not burdened by anything and who do not care about politics and money, "but they are only interested in a thing and go for it. The sincerest ideas come from there, and the most potential can also be wasted [because of their interests] or built [from them]."

Most secondary schools in Slovenia develop the entrepreneurial competencies of their students, although some of them avoid 'entrepreneurship' labelling. They introduce project work, thematic days, entrepreneurial classes, and similar activities. In addition to the entrepreneurship class, where students learn about business operations, the gymnasium in question introduced experiential forms of work with students, involved them in projects with local companies and associations, and encouraged them to volunteer and organise the school's social life. To use the words of the interlocutors, the school found a way to raise a "typical" teenager - whom Jakob describes as: "[A teenager] would sleep. That's it. He would sleep and eat" - into "a whole man. That it is not only about the Matura of a 'kindergarden teacher', but that it is about Jakob with the knowledge that goes beyond the Matura, beyond this certificate." In other words, the school shapes the student into a person who is emphatic, willing to help, and able to critically assess where and when he/she needs to intervene. Despite the fact that activation, performance, and responsibilisation frame children as neoliberal subjects (Berglund et al. 2017), the school tries to mitigate this tension by encouraging "students-as-givers" who create value for others (Lackéus 2017). The willingness of teachers to try new pedagogical approaches as well as the interviews with students show that they view its approach as the opposite of neoliberalism.

This outcome illustrates how schools operating in the system, which is often accused - in Matija's words - of "making people lazy" or of raising individualistic, competitive, and narcissistic students (Vodopivec Kolar 2013), try to raise young people into active citizens with certain anti-neoliberal values despite equipping them with the entrepreneurial knowledge, skills, and competences commonly regarded as neoliberal. This example can inform policy-makers in the fields of education and entrepreneurship that schools do not unequivocally adopt (new) policies and directions. Some of them actively engage with policies and adjust (or 'bend') national guidelines for (what they perceive as) a better outcome because they recognise neoliberalism as something potentially negative. Teachers find the attempts to keep young people from turning into "passive consumers" or "tycoons" important and rather try to shape them into emphatic people caring for the welfare of society, so developing entrepreneurial qualities - or entrepreneurship in general - needs to be handled with care and should not be the only virtue that schools cultivate.

Future research on the phenomenon could benefit from ethnographic studies 
focusing on 'average', non-entrepreneurial students and schools omitted from this study. However, by relying on the exemplary entrepreneurship education regarding teaching methods and self-reflection, which were presented in this article, this research nevertheless challenges critical neoliberal theory by revealing that current educational institutions, despite striving to develop students' entrepreneurial skills and competences, feel the need to mitigate neoliberal tendencies and thus are working towards instilling seemingly anti-neoliberal values in the students.

\section{REFERENCES}

BAJIČ, Blaž. 2015. "Ustvarjanje prostorov ustvarjalnosti: sodobni rokodelski sejmi v Ljubljani kot produkcija lokalnosti". Traditiones, vol. 44/3:149-170. DOI: https://doi.org/10. 3986/Traditio2015440308

BAJUK SENČAR, Tatiana. 2021. "Conceptualizing Youth Entrepreneurship in EU Policy Discourse". Studia ethnologica Croatica, vol. 33:021-042. DOI: https://doi.org/10. 17234/SEC.33.4

BENAK CVIJANOVIĆ, Vanessa and Rene DOPLER. 2020. "Podjetništvo v šolskih klopeh: etnografija spodbujanja podjetniške kreativnosti na šoli v Novem mestu". Glasnik Slovenskega etnološkega društva, vol. 60/2:30-41. URL: https://cdn.domdesign. com/users/SEDDrustvo/Site/sites/sed-drustvo.si/modules/Domino/Files/glasnik60-2-2020.pdf (accessed 17 April 2021).

BERGLUND, Karin, Monica LINDGREN and Johann PACKENDORFF. 2017. "Responsibilising the Next Generation: Fostering the Enterprising Self through De-mobilising Gender". Organization, vol. 24/6:892-915. DOI: https://doi.org/10.1177/135050 8417697379

BRUNILA, Kristiina. 2012. "A Diminished Self: Entrepreneurial and Therapeutic Ethos Operating with a Common Aim". European Educational Research Journal, vol. 11/4:477-486. DOI: https://doi.org/10.2304/eerj.2012.11.4.477

COMMISSION OF THE EUROPEAN COMMUNITIES. 2003. Green Paper: Enterpreneurship in Europe. URL: https://ec.europa.eu/invest-in-research/pdf/download en/entreprene urship_europe.pdf (accessed 17 April 2021).

DAHLSTEDT, Magnus and Andreas FEJES. 2019. "Shaping Entrepreneurial Citizens: A Genealogy of Entrepreneurship Education in Sweden". Critical Studies in Education, vol. 60/4:462-476. DOI: https://doi.org/10.1080/17508487.2017.1303525

DINGLI, Sandra. 2009. "Thinking Outside the Box: Edward de Bono's Lateral Thinking”. In The Routledge Companion to Creativity, eds. Tudor Rickards, Mark A. Runco and Susan Moger. London: Routledge, 338-350.

EUROPEAN COMMISSION. 2010. Europe 2020: A European Strategy for Smart, Sustainable and Inclusive Growth. URL: https://ec.europa.eu/eu2020/pdf/COMPLET\%20 
EN\%20BARROSO\%20\%20\%20007\%20-\%20Europe\%202020\%20-\%20EN\%20 version.pdf (accessed 17 April 2021).

EUROPEAN UNION. 2006. Recommendation of the European Parliament and of the Council on Key Competences for Lifelong Learning. URL: https://eur-lex.europa.eu/LexUri Serv/LexUriServ.do?uri=OJ:L:2006:394:0010:0018:en:PDF (accessed 17 April 2021).

FAYOLLE, Alain and Heinz KLANDT. 2006. "Issues and Newness in the Field of Entrepreneurship Education: New Lenses for New Practical and Academic Questions". In International Entrepreneurship Education, eds. Alain Fayolle and Heinz Klandt. Cheltenham - Northhampton: Edward Elgar, 1-17.

FOUCAULT, Michel. 1988. "Technologies of the Self". In Technologies of the Self: A Seminar with Michel Foucault, eds. Luther H. Martin, Huck Gutman and Patrick H. Hutton. Amherst: The University of Massachusetts Press, 16-59.

FREEMAN, Carla. 2014. Entrepreneurial Selves: Neoliberal Respectability and the Making of a Caribbean Middle Class. Durham - London: Duke University Press.

GEA COLLEGE. [s. a.]. "History". URL: https://gea-college.si/en/o-\%20gea-college-2\%20 /\%20zgodovina\%20/ (accessed 15 April 2021).

GLAS, Miroslav, Mateja DRNOVŠEK, Tjaša ERLIH, Bogomir KOVAČ, Karmen KRANJEC, Miroslav REBERNIK, Matej RUS and Senka ŽERIČ. 2006. Predlog strategije uvajanja podjetništva v redni šolski sistem 2007-2013. Ljubljana: Univerza v Ljubljani - Ekonomska fakulteta, Center za razvoj podjetništva. URL: https://sku pnost.sio.si/pluginfile.php/446200/mod_page/content/1/Slovenski_dokumenti/ Glas_idr_Strategija_uvajanja_podjetnistva_v_solski_sistem_2006.pdf (accessed 12 October 2020).

HARVEY, David. 2005. A Brief History of Nationalism. New York: Oxford University Press.

HONEYMAN, Catherine A. 2016. The Orderly Entrepreneur: Youth, Education, and Governance in Rwanda. Stanford: Stanford University Press.

HOUGHTON, Elizabeth. 2019. "Becoming a Neoliberal Subject". Ephemera, vol. 19/3:615626. URL: http://www.ephemerajournal.org/sites/default/files/pdfs/contribution /19-3houghton_0.pdf (accessed 17 April 2021).

KOMULAINEN, Katri, Päivi NASKALI, Maija KORHONEN and Seija KESKITALO-FOLEY. 2011. "Internal Entrepreneurship: A Trojan Horse of the Neoliberal Governance of Education? Finnish Pre- and In-service Teachers' Implementation of and Resistance towards Entrepreneurship Education". Journal for Critical Education Policy Studies, vol. 9/1:341-347. URL: http://www.jceps.com/wp-content/uploads/ PDFs/09-1-13.pdf (accessed 18 May 2021).

KOZOROG, Miha. 2018a. "The Ecosystem Ideal and Local Neoliberalism of the Young Entrepreneur: The Millennials' Entrepreneurial Environment in Slovenia". Etnološka tribina, vol. 48/41:259-280. DOI: https://doi.org/10.15378/1848-9540.2018.41.10

KOZOROG, Miha. 2018b. "'Normalen podjetnik' vs. 'poseben aktivist': iskanje ravnovesja med osebo in prihodnostjo". Glasnik Slovenskega etnološkega društva, vol. 58/3 -4:51-63. URN: http://www.dlib.si/details/URN:NBN:SI:doc-TIWVJ4GY 
KOZOROG, Miha. 2019. "Trije časi podjetništva mladih v Sloveniji". Glasnik Slovenskega etholoskega društva, vol. 59/2:19-32. URN: http://www.dlib.si/details/URN:NBN:SI: DOC-4YFH1QZI

LAALO, Hanna, Heikki KINNARI and Heikki SILVENNOINEN. 2019. "Setting New Standards for Homo Academicus: Entrepreneurial University Graduates on the EU Agenda". European Education, vol. 51/2:93-110. DOI: https://doi.org/10.1080/10564934.2 018.1489729

LACKÉUS, Martin. 2017. "Does Entrepreneurial Education Trigger More or Less Neoliberalism in Education?" Education + Training, vol. 59/6:635-650. DOI: https://doi.org/10. 1108/ET-09-2016-0151

LISBON EUROPEAN COUNCIL. 2000. Presidency Conclusions. URL: https://www.consilium. europa.eu/ueDocs/cms_Data/docs/pressData/en/ec/00100-r1.en0.htm (accessed 17 April 2021).

MILLEI, Zsuzsa. 2020. "Child as Human Capital". In The SAGE Encyclopedia of Children and Childhood Studies (Vols. 1-4), ed. Daniel Thomas Cook. Thousand Oaks: SAGE, 929-932.

MLADI IN PODJETNIŠTVO. [s. a.]. URL: https://www.podjetniski-portal.si/mladi-in-podjetnistvo (accessed 10 April 2021)

MWASALWIBA, Ernest Samwel. 2010. "Entrepreneurship Education: A Review of Its Objectives, Teaching Methods, and Impact Indicators". Education + Training, vol. 52/1:20-47. DOI: https://doi.org/10.1108/00400911011017663

OLSSEN, Mark and Michael A. PETERS. 2005. "Neoliberalism, Higher Education and the Knowledge Economy: From the Free Market to Knowledge Capitalism". Journal of Education Policy, v ol. 20/3:313-345. DOI: https://doi.org/10.1080/02680930 500108718

PLUT, Helena and Tadeja PLUT. 1995. Podjetnik in podjetništvo. Ljubljana: Znanstveno in publicistično središče.

POLJAK ISTENIČ, Saša. 2015. "Kolo kot akter ustvarjalne urbane regeneracije". Glasnik Slovenskega etnološkega društva, vol. 55/3-4:23-37. URN: https://www.dlib.si/ details/URN:NBN:SI:DOC-RUJ3FQ1B

POLJAK ISTENIČ, Saša. 2017. "Creativity: An Introduction to Popular Concepts, Topics, and Discussions". Traditiones, vol. 46/1-2:103-125. DOI: https://doi.org/10.3986/ Traditio2017460201

ROBINSON, Sarah and Wesley SHUMAR. 2014. "Ethnographic Evaluation of Entrepreneurship Education in Higher Education: A Methodological Conceptualization". The International Journal of Management Education, vol. 12/3:422-432. DOI: https://doi.org/10.1016/j.ijme.2014.06.001

ROSE, Nikolas S. 1998. Inventing Our Selves: Psychology, Power and Personhood. Cambridge: Cambridge University Press.

SIMONIČ, Peter. 2021. "The Role of Social Institutions in the Operation of Maribor Start-ups and Cooperatives after Economic Crisis in 2008". Studia ethnologica Croatica, 
vol. 33:069-096. DOI: https://doi.org/10.17234/SEC.33.6

SSKJ. 2014. "Tajkun”. URL: https://fran.si (accessed 25 August 2021).

STATISTICAL OFFICE. 2005. URL: https://www.stat.si/doc/letopis/2005/06_05/06-05-05.htm (accessed 17 April 2021).

SUN. [s. a.]. "Zgodovina". URL: https://www.sun.si/o-podjetju/zgodovina/ (accessed 7 October 2020).

TESTA, Stefania and Silvana FRASCHERI. 2015. "Learning by Failing: What We Can Learn from Un-successful Entrepreneurship Education". The International Journal of Management Education, vol. 13/1:11-22. DOI: https://doi.org/10.1016/j.jime.2014. 11.001

TRAMPUŠ, Marina. 2016. "Podjetništvo v osnovne šole". URL: https://podjetnik.net/ podjetnistvo-v-osnovne-sole-mag-marina-trampus/ (accessed 5 May 2021).

TURK NISKAČ, Barbara. 2021. "Distance Learning and New Forms of Discipline during the Pandemic". Narodna umjetnost, vol. 58/1:85-106. DOI: https://doi.org/10. 15176/vol58no105

VALDEZ, Zulema. 2011. The New Entrepreneurs: How Race, Class, and Gender Shape American Enterprise. Palo Alto: Stanford University Press.

VODOPIVEC, Nina. 2017. "Creativity in Production and Work: Experiences from Slovenia". Traditiones, vol. 46/1-2:127-147. DOI: https://doi.org/10.3986/Traditio2017460202

VODOPIVEC, Nina. 2018. "Vizije prihodnosti in družbene spremembe v Sloveniji: podjetništvo, socialno podjetništvo in družbeno eksperimentiranje". Glasnik Slovenskega etnološkega društva, vol. 58/3-4:39-49. DOI: https://www.dlib.si/details/URN: NBN:SI:DOC-ZJE4K2OH

VODOPIVEC KOLAR, Katarina. 2013. "Antropološka analiza narcisizma v izbranih slovenskih osnovnih šolah". In Drugo pedagoškega diskurza, ed. Vesna Pobežin. Ljubljana: Pedagoški inštitut, 147-168. URL: http://os-domzale.splet.arnes.si/files/2014/01/ clanek_kvk.pdf (accessed 20 May 2021).

WACH, Krzysztof. 2014. "Europeanisation of Entrepreneurship Education in Europe: Looking Back and Looking Forward". Horyzonty Wychowania, vol. 13/26:11-31. URL: https://horyzonty.ignatianum.edu.pl/HW/article/view/56/46 (accessed 10 April 2021).

WINGFIELD, Adia Harvey and Taura TAYLOR. 2016. "Race, Gender, and Class in Entrepreneurship: Intersectional Counterframes and Black Business Owners". Ethnic and Racial Studies, vol. 39/9:1676-1696. DOI: https://doi.org/10.1080/01 419870.2016.1178789 


\section{Kako odgojiti poduzetnika? Promicanje poduzetništva u slovenskom srednjoškolskom obrazovanju}

\section{Saša Poljak Istenič}

Na temelju studije slučaja jedne slovenske srednje škole, autorica se u radu bavi nacionalnim specifičnostima i europskim orijentacijama poduzetničkog obrazovanja. Svrha je rada ilustrirati i kritički komentirati kako obrazovne mogućnosti oblikuju kreativnost učenika. $U$ nastavku se rad temelji na povijesnom pregledu razvoja obrazovanja u Sloveniji i narativnim intervjuima s učiteljima, ravnateljima, mentorima i (bivšim) učenicima. Analiza pridonosi standardnoj raspravi o neoliberalizaciji suvremenog obrazovanja u kojoj se djeca shvaćaju kao ljudski kapital, a otkriva kako se škola s učenicima redovito uključuje u izvannastavne aktivnosti kojima bi ublažila paradigmu neoliberalizacije: njeguje volontiranje, rješava lokalne probleme i promovira kritičku procjenu je li intervencija uopće potrebna.

Ključne riječi: poduzetničko obrazovanje, srednje škole, (ublažavanje) neoliberalizma, učenici kao davatelji

\section{Kako vzgojiti podjetnika? Spodbujanje podjetništva v slovenskem srednješolskem izobraževanju}

\section{Saša Poljak Istenič}

Članek na podlagi študije primera slovenske srednje šole obravnava nacionalne posebnosti in evropske usmeritve podjetniškega izobraževanja. Njegov namen je ponazoriti, kako izobraževalne priložnosti oblikujejo tvornost dijakov. Temelji na zgodovinskem pregledu njegovega razvoja v Sloveniji in narativnih intervjujih z učitelji, ravnatelji, mentorji in (nekdanjimi) dijaki. Analiza doprinaša k standardni razpravi o neoliberalizaciji sodobnega izobraževanja, v katerem se otroke razume kot človeški kapital, hkrati pa razkriva, kako šola sodeluje z dijaki v rednih programih in obšolskih dejavnostih, da bi omilila obtožbe o neoliberalizaciji: neguje prostovoljstvo, obravnava lokalne probleme in spodbuja kritično presojo, ali je posredovanje sploh potrebno.

Ključne besede: podjetniška vzgoja, srednje šole, (blaženje) neoliberalizma, dijaki-kot-dajalci 
Articles published in this journal are Open Access and can be distributed under the terms and conditions of the Creative Commons license Attribution-NonCommercial-NoDerivatives 4.0 (http://creativecommons.org/licenses/by-nc-nd/4.0/) 